Discussion Paper No. 593

\title{
MANAGEMENT OWNERSHIP AND FIRM'S VALUE: AN EMPIRICAL ANALYSIS USING PANEL DATA
}

\author{
Sang-Mook Lee \\ and \\ Keunkwan Ryu
}

September 2003

The Institute of Social and Economic Research Osaka University

6-1 Mihogaoka, Ibaraki, Osaka 567-0047, Japan 


\title{
Management Ownership and Firm's Value: An Empirical Analysis using Panel Data
}

\author{
by \\ Sang-Mook Lee \\ Samsung Research Institute of Finance \\ and \\ Keunkwan Ryu \\ ISER, Osaka University \\ and \\ Department of Economics \\ Seoul National University
}

August 5, 2003

\begin{abstract}
Demsetz and Lehn (1985), Morck, Shleifer, and Vishny (1988), and McConnell and Servaes (1990) report different empirical findings regarding ownership structure and corporate profitability. In this paper, we re-estimate the relation between management ownership and firm's value after controlling for the history of management ownership as well as inter-firm differences using panel data. Further, we consider the possibility that the current ownership structure is jointly determined with the firm value, an endogeneity argument a la Demsetz (1983). We find that history of the management ownership, not its current level, matters in determining the firm value, which is consistent with information asymmetry arguments.
\end{abstract}

Keywords: convergence-of-interest, endogeneity, entrenchment, firm value, information asymmetry, insider ownership, panel data

JEL Classification: C23, C81, D23

Keunkwan Ryu is the corresponding author. He is currently an Associate Professor, Department of Economics, Seoul National University, Korea, and Visiting Foreign Scholar, ISER, Osaka University, Japan. His mailing address is Department of Economics, Seoul National University, Seoul 151-742, Korea, phone number is 82-2-880-6397, fax number is 82-2-886-4231, and email address is ryu@snu.ac.kr. 


\section{Introduction}

In his path breaking work, Demsetz (1983) argues that a firm's ownership structure is endogenously determined to maximize its shareholders' interest. Accordingly, Demsetz concludes that there is no relation between ownership structure and profitability. Demsetz and Lehn (1985) present evidences supporting Demsetz's arguments. They regress accounting profit rates of 511 U.S. companies in 1980 on different measures of ownership concentration and they find no significant coefficient.

In contrast, two subsequent papers, Morck, Shleifer, and Vishny (1988) and McConnell and Servaes (1990), report quite different findings. Morck, Shleifer, and Vishny estimate a piece-wise linear regression in which the dependent variable is Tobin's Q and the primary independent variable is the fraction of shares owned by corporate management. Using a cross-section sample of 371 Fortune 500 firms for 1980, they find that Q first rises as management ownership increases to $5 \%$, then falls as ownership increases to $25 \%$, and then rises slightly at higher ownership levels. When they use profit rates as an alternative dependent variable they find similar piece-wise linear relationship, even though the statistical significance of the estimates is much lower. They mention that their results appear at odds with the findings of Demsetz and Lehn. They suggest that Demsetz and Lehn fail to capture the non-monotonic relationship that they have found by estimating a mis-specified linear model rather than a piece-wise linear model.

McConnell and Servaes (1990) investigate the cross-sectional relation between Tobin's Q and management equity ownership for a sample of 1,173 firms in 1976 and for a sample of 1,093 firms in 1986 that are listed on either the New York Stock Exchange or the American Stock Exchange. For both samples, they find a significant curvilinear relation between Tobin's Q and the management ownership. Q first increases, then decreases, as the shares become concentrated in the hands of managers and members of the board of directors. They also mention that their results are consistent with neither Demsetz's (1983) theoretical arguments nor Demsetz and Lehn's (1985) empirical findings. They do not offer any possible theoretical or empirical explanation for the inconsistency, though.

These three empirical results are mutually contradictory. How could these conflicting results coexist side by side? In this paper, we re-investigate the relation between management ownership and firm's value using panel data rather than crosssectional data. The advantage of using panel data is that we are able to control for unobservable firm-specific attributes and past history of insider ownership changes to better single out the relationship between insider ownership and the firm value.

According to Demsetz, insider ownership is endogenously determined to maximize the firm value given firm-specific characteristics. If so, controlling for unobservable firm-specific effects and for ownership patterns in the past as well for the observable characteristics, would mitigate the endogeneity problem of the current ownership variable in determining the firm value. Also, by using panel data, we even 
allow for the possibility that the ownership variable is still endogenous. Accounting for endogeneity is easier in the panel data setting than in the cross-sectional data.

Note that all three of the previous studies use cross-sectional data. Crosssectional studies would make any sense at all only when the management shareholding is stable over time. Seyhun (1992) reports that in spite of the increased statutory sanctions of the 1980s on the insider trading, data show increases in volume and abnormal profits of insider trading over time. The management shareholding is not stable over time. Unlike cross-sectional data, panel data allows one to take into account the effect on the firm value of the history of management ownership changes.

We argue that the extent of insider trading and the changing pattern of management ownership have to be controlled to single out the relation between management ownership and the firm value. Under information asymmetry between the management and the outside investors, intensive insider trading raises the possibility that the informed management exploits the uninformed outside investors. When we include a variable measuring the extent of insider trading in the regression, we expect its coefficient to be negative as a result. Outside investors take changes in the management ownership between the previous year and the current year, as a credible signal about the firm's future performance. When we include the change in the management ownership in the regression, we expect its coefficient to be positive.

The above arguments imply that firms with identical management shareholding at a specific time can display quite different corporate values. For example, consider two firms with the same level of management shareholding. If one firm's management reduces its shareholding recently, the firm's market value would be lower than that of the other firm that has stable management shareholding. Without controlling for the history of management shareholdings, we face difficulties in identifying relation between management shareholding and firm's value. Cross-sectional analyses do not account for the history of management shareholdings. Empirical findings in crosssectional studies much depend on the specific sample being used. We argue that this partly explains why the afore-mentioned previous studies report mutually conflicting results.

Another advantage of using panel data lies in that one can better control for unobservable inter-firm differences. Many of the firm characteristics are not observed, but still important. Another possible explanation for differences among afore-mentioned empirical results is that there may be unidentified, but important, inter-firm differences. Panel data allow us to better control for unobserved inter-firm differences, enabling us to better single out the relation between management ownership and firm's value.

Panel data analyses of this paper, by being able to control for unobservable inter-firm differences and history of management ownership, are expected to better reveal the relationship between management ownership and the firm value. In this way, we hope to see whose theory, Demsetz's or the others', is more appropriate.

The rest of the paper is organized as follows. Section 2 reviews the existing 
literature on the relation between the management ownership and the firm value. Section 3 draws testable hypotheses. Section 4 explains the data and presents the estimation results. Section 5 concludes the paper.

\section{Ownership structure and corporate value}

Berle and Means (1932) point out that potential conflicts of interest arise between corporate managers and dispersed shareholders when managers do not have an ownership interest in the firm. After Berle and Means' seminal paper, various aspects of this so-called agency problem have been analyzed. Among others, Jensen and Meckling (1976) formalize the relation between managerial equity ownership and the corporate value. They divide stockholders into two groups, inside shareholders who manage the firm and outside shareholders who do not. Both classes of shareholders are entitled to the same dividends per share. The inside shareholders, however, are able to augment their cash flows by additionally consuming non-marketable perquisites. In this framework, there is an incentive for the manager to adopt investment and financing policies that benefit him, but cost the outside stockholders. Thus, the firm value depends on the fraction of shares owned by the management. The greater the management share, the greater the firm value.

Fama and Jensen (1983) point out offsetting costs of significant management ownership. When a manager only owns a smaller stake, he is disciplined toward firm value maximization by the market forces such as the managerial labor market (Fama 1980), the product market (Hart 1983), and the corporate control market (Jensen and Ruback 1983; Stulz 1988). In contrast, when a manager controls a substantial fraction of the firm's equity, he can entrench himself from these market disciplines. With effective control, the manager may indulge in non-value-maximizing behaviors such as high salary and empire building. This entrenchment possibility predicts that corporate assets become less valuable when the management holds a significant portion of shares.

What Morck, Shleifer, and Vishny (1988) and McConnell and Servaes (1990) try to accomplish is to document how these two offsetting forces are realized in real firms using cross-section data. Morck et al. write on this point as follows:

"Theoretical arguments alone cannot unambiguously predict the relationship between management ownership and market valuation of the firm's assets. While the convergence-of-interest hypothesis suggests a uniformly positive relationship, the entrenchment hypothesis suggests that market valuation can be adversely affected for some range of high ownership stakes."

Morck et al. point out that it is not possible, a priori, to predict which force will dominate at any level of managerial ownership. Thus, they argue that the relation between ownership structure and corporate value is an empirical issue.

Demsetz (1983) argues that the ownership structure of a firm is an endogenous outcome of competitive selection in which various cost advantages and disadvantages 
are balanced to arrive at an equilibrium organization of the firm. He writes as follows:

"One cannot simply assert that diffuse ownership fails to yield maximum profit or maximum value of the firm. A decision by shareholders to alter the ownership structure of their firm from concentrated to diffuse should be a decision made in awareness of its consequences for loosening control over professional management. The higher cost and reduced profit that would be associated with this loosening in ownership control should be offset by lower capital acquisition cost or other profitenhancing aspects of diffuse ownership if shareholders choose to broaden ownership."

Accordingly, he concludes that ownership concentration and profit rate should be unrelated.

As mentioned above, Demsetz and the others suggest quite different implications about the relation between management ownership and firm's performance. Demsetz argues that there should not be any significant relation between management ownership and firm's performance with a few possible exceptions that we would mention below. In contrast, the others argue that theory itself cannot tell much about the specific relation between management ownership and firm's value. They say it is rather an empirical issue.

How could Demsetz and the others suggest quite different implications? We think the fundamental source of difference lies in the way of interpreting management perquisite consumption. Morck et al. seem to think that management can indulge in non-marketable perquisite consumption at the expense of outside shareholders. There are two countervailing forces in this regard. On one hand, as the management ownership increases, the management itself bears the greater portion of the cost of perquisite consumption, which will enhance self-discipline on perquisite consumption. On the other hand, as the management ownership increases, the management effectively protects himself from market discipline on perquisite consumption, which will reduce external discipline on perquisite consumption. There exists a trade-off between selfdiscipline and external discipline as the management ownership changes. As they point out, their theory does not tell us anything about whether management's optimal perquisite consumption increases or decreases as the management ownership changes. It is to be found empirically.

In addition, the management ownership level is exogenous in their theory. Determinants of management ownership are beyond their theory. Why does the management of some firms possess large ownership share, whereas the management of others does not? If there exists an optimal level of the management ownership most appropriate to maximize the perquisite consumption, why does the management not try to adjust its ownership to the optimal level? Their theory does not address these questions.

According to Demsetz, there is no free lunch. If there exists a possibility for 
management to indulge in excessive perquisite consumption at the cost of outside shareholders, rational investors would take into account this possibility and try to make management bear the full cost of expected perquisite consumption at the time they invest in the firm. The resulting outcome is desirable for neither the management nor the outside investors. Both management and outside investors would be better off if they find some mechanisms to reduce perquisite consumption. To Demsetz, increasing management ownership is a way of reducing this agency problem through the management's self commitment not to indulge in excessive perquisite consumption, and therefore it is not right to say that increase in management ownership causes higher agency cost through effective entrenchment.

Rather, in Demsetz's theory, the cost of increasing management ownership arises from a different source. To increase management ownership, the management should invest a larger portion of its wealth in the firm he manages. This means that the management should take higher firm-specific risks and forgo benefits of diversification. To induce increased management ownership, the firm or the investors as a whole should compensate the management for bearing these higher risks, or for sacrificing diversification. This compensation will raise capital cost of the firm. Also, given the size of the management wealth, maintaining a high level of management ownership restricts the firm size and thus economies of scale in production. There exists a trade-off between agency cost on one side, and capital cost and production cost on the other. In the process of firm's value maximization considering these trade-offs, shareholders as a whole (including the management) determine the general ownership structure and the management ownership. In Demsetz's firms, management ownership level is determined endogenously together with other factors affecting the firm performance, leading to lack of any significant relation between the management ownership and the firm value.

In his recent book, Demsetz (1995, pp. 66-72) recognizes that there might be one possible exception to this prediction on the relation between ownership structure and firm's performance. Demsetz suggests that if the management indulges in amenity consumption and he has sufficient wealth to persist in amenity consumption, the recorded performance and market value of the firm can be depressed in equilibrium. Here, amenity is defined as the way firm's assets are used and the nature of the product the firm produces. Demsetz write as follows:

"An individual who owns a newspaper might derive utility from influencing the political tastes of readers. Catering to this preference may come at the expense of profit, for readers might not relish continued exposure to the owner's political philosophy in the news and editorializing given to them, and it certainly will alter the content of the newspaper as compared to one designed simply to maximize profit."

In this case, the management would rather continue amenity consumption even though he should fully pay for it in the form of low profit and low market valuation of his firm. This is more likely to be sustained in those firms where the incumbent management holds large enough shares to secure control over the firm from corporate control market. If this kind of amenity consumption is a dominant motive for the management to hold 
large, sometimes majority, shares, we expect to see low performance in those firms with large management ownership.

We suggest another channel through which the management ownership affects the firm value. Investors, ex ante, can ask full payment for the expected management perquisite consumption. Management may indulge in more perquisite consumption ex post than expected ex ante at the cost of outside shareholders. The occurrence of this event will lower firm's performance than implicitly contracted for. There exists a possible remedy for this. Takeover is that. Takeover can eliminate excessive ex post perquisite consumption. Accordingly, we expect to run into management indulging in excessive ex post perquisite consumption more frequently in firms where the management owns a large enough share and thus the takeover threats do not work. This conjecture leads to the empirical implication that there will be negative relation between management ownership and the firm performance.

As a measure of firm's performance, Morck et al. and McConnell et al. use Tobin's Q, whereas Demsetz and Lehn use profit rate. Does it matter whether one uses firm's market value or profit rate as a measure of firm's performance?

Firm's market value reflects future profitability of the firm as well as current profit. On top of these, as market micro structure theory suggests, the market value might be affected by the extent of information asymmetry, frequency or volume of insider trading, and liquidity whereas profit stream is quite immune to these elements. As a result, the recorded rate of return may differ across investors and securities being traded. For example, if there exists a significant difference in liquidity between two equities, the less liquid equity should offer a higher recorded return enough to offset reduction in liquidity to induce investors to buy the equity.

Regarding this, Demsetz (1986) suggests quite an intuitive interpretation for insider trading and its effects on recorded rate of return. Demsetz asks whether insider trading is a way of compensation to management for bearing a higher firm-specific risk, and whether investors take into account the possibility of exposure to insider trading when they trade equity of the firm. Demsetz and Lehn (1985) show that firms with high firm-specific risks tend to have more concentrated ownership structure. Demsetz (1986) reports that there exists a positive correlation between the degree of insider trading and the firm-specific risk, and a negative correlation between the degree of insider trading and the recorded market rates of return. Demsetz interprets this empirical result as an indirect evidence supporting that insider trading is a way of compensation to controlling shareholders for taking a high firm-specific risk, and that investors discount stocks being actively traded by insiders.

If investors ask price discount for the equities insiders are intensively trading, and if insider trading is one way of compensation to management for bearing a higher firm-specific risk, then increasing management ownership will depress market price of equity of the firm in equilibrium. From this, we can expect a negative relation between the management ownership and the firm's market value even when there is no significant relation between the management ownership and the firm's performance in 
terms of profit rate. We expect to see that the relation between the firm value and the management ownership would be relatively more negative in the case of using market value as the dependent variable than in the case of using profit rate as the dependent variable.

\section{Hypotheses}

In this paper, we investigate the relation between the management ownership and the firm value after controlling for unidentified inter-firm differences and the history of management ownership changes using panel data. Management is defined as officers and directors as usual.

First, we consider the history of management ownership of a firm as an important factor that can possibly affect the firm's market value. More specifically, we test a hypothesis that firm's market value be negatively affected by the extent of management's insider trading. We also test another hypothesis that firms market value be positively affected by an increase in management ownership, which is measured by the difference of management shareholding between the current year and the previous year.

Under asymmetric information between management and outsiders, a firm experiencing intensive insider trading would incur higher implicit transaction cost to uninformed outsiders. This perception would lead outsider investors to ask price discount when they buy such a firm's equity. Also, the direction and amount of change in management shareholding between two consecutive years can be interpreted as the existence of insider's private information about the future profitability of the firm. When the management shareholding increases, it would have positive effect on the firm's market value because uninformed outsiders would interpret it as the existence of high profit opportunity in the future. With this perception, outsider investors would be willing to pay premium when they buy such a firm's equity.

\section{Data and results}

\subsection{Data}

In this analysis, price-earnings ratio is regressed against the measures of ownership and other control variables. Tobin's Q has been used by many studies including Morck et al. and McConnell et al.

Tobin's Q has some defects to be used as a measure of firm's value. First, the process of computing it inevitably entails some arbitrariness. For example, it is hard to find objective criteria to compute replacement costs. Second, as Bagnani, Milonas, Saunders, and Travlos (1994) point out, market price of risky debt may also be affected by management ownership. If this is the case, we should use market price of debt when we use Tobin's Q as a measure of firm's market value, which was not the case in previous studies. Further, if we use market prices of debt to take into account this point, Tobin's Q would not anymore be an appropriate measure of firm's value from 
shareholders' perspectives, rather it is a measure of firm's market value from general claim holder's perspective.

Price-earnings ratio does not face these problems. It does not require any arbitrary computing process. In price-earnings ratio, earnings can be considered as a measure of opportunity cost of shareholders' capital, and price of equity is the right measure of firm's market value from shareholders' perspectives. So, in this paper, we use price-earnings ratio as a measure of firm value.

This paper uses data on 11 firms in the chemical industry. For each sample firm, we have annual data from 1981 through 1990, resulting in 110 (firm, year) combinations. As the data source, we use the Value Line Investment Survey which is being widely used in related works.

\subsection{Estimation results}

We estimate three panel data models: pooled least squares, fixed effects, and random effects models. The pooled least squares treats time-series data of a firm just as different firms at a point in time. This method does not utilize information on who's who regarding firm identity. The reason why we still report the pooled least squares results is twofold. One is that, even though it has the afore-mentioned defect, the pooled least squares effectively maximizes the sample size. The other, more important, reason is that the pooled least squares is similar to the cross sectional analyses in that it does not control for unidentified inter-firm differences even though it controls for the history of management ownership. Table 1 shows the results of the pooled least squares, which serve as a benchmark for interpreting the panel estimation results in table 2 .

In table 1, when we initially regress price-earnings ratio on management ownership share, we obtain a negative linear relation between management shareholding and price-earnings ratio. When we include the variance of or the change in management shareholding as a proxy for insider trading, the proxy variable turns out significant, whereas the management shareholding itself loses statistical significance. Column 5 shows that the coefficient of the variance of management shareholding is negative and statistically significant at $1 \%$ significance level, whereas the coefficient of the level of management shareholding is insignificant even at $10 \%$ level. Column 6 shows that the coefficient of the change in management ownership is positive and statistically significant at $1 \%$ level, whereas the level of management ownership is insignificant at $10 \%$ level. 


\section{Table 1. Results from the pooled least squares}

Pooled least squares regression of price-earnings ratio on equity ownership, variance of management shareholding, change in management shareholding, dividend per share, debt ratio, expected growth rate of earnings per share, and variance of earnings per share.

\begin{tabular}{|c|c|c|c|c|c|c|}
\hline & (1) & (2) & (3) & (4) & (5) & (6) \\
\hline Intercept & $\begin{array}{l}15.42 * * \\
(44.92)\end{array}$ & $\begin{array}{c}15.44 * * \\
(37.03)\end{array}$ & $\begin{array}{c}15.14^{* *} \\
(36.20)\end{array}$ & $\begin{array}{l}15.67 * * \\
(32.84)\end{array}$ & $\begin{array}{c}14.78^{* *} \\
(17.84)\end{array}$ & $\begin{array}{c}15.80 * * \\
(18.31)\end{array}$ \\
\hline Insider & $\begin{array}{c}-0.06 * * \\
(-5.27)\end{array}$ & $\begin{array}{c}-0.68 \\
(-1.34)\end{array}$ & & & $\begin{array}{c}0.01 \\
(0.27)\end{array}$ & $\begin{array}{l}-0.03 \\
(-1.20)\end{array}$ \\
\hline insider $^{\wedge} 2$ & & $\begin{array}{c}0.00 \\
(0.15)\end{array}$ & - & & & \\
\hline insider+block & & & $\begin{array}{l}-0.04^{*} \\
(-2.22)\end{array}$ & $\begin{array}{c}-0.15^{* *} \\
(-2.79)\end{array}$ & - & \\
\hline$($ insider+block)^2 & & & & $\begin{array}{l}0.003^{*} \\
(2.41)\end{array}$ & - & \\
\hline var(insider) & & & & & $\begin{array}{c}-0.04 * * \\
(-3.45)\end{array}$ & \\
\hline change(insider) & & & & & & $\begin{array}{c}0.13 * * \\
(2.92)\end{array}$ \\
\hline Dividend & & & & & $\begin{array}{c}3.03 * * \\
(3.43)\end{array}$ & $\begin{array}{c}1.00 \\
(1.48)\end{array}$ \\
\hline Debt & & & & & $\begin{array}{c}-3.86 * * \\
(-2.67)\end{array}$ & $\begin{array}{c}-5.43 * * \\
(-3.46)\end{array}$ \\
\hline $\mathbf{r}_{-} \mathbf{E} / \mathbf{S}$ & & & & & $\begin{array}{c}3.19 * * \\
(4.05)\end{array}$ & $\begin{array}{c}2.70 * * \\
(3.22)\end{array}$ \\
\hline $\operatorname{var}(E / S)$ & & & & & $\begin{array}{c}-2.15^{* *} \\
(-3.08)\end{array}$ & $\begin{array}{l}-0.95 \\
(-1.55)\end{array}$ \\
\hline
\end{tabular}

1. Within parentheses are t-values.

2. Variables are defined as follows
(a) insider: fraction of management share (\%),
(b) insider+block: sum of management share and outside block holder share (\%),
(c) var(insider): variance of "insider" over time,
(d) change(insider): change in "insider" between the previous year and the current year,
(e) dividend: dividend per share,
(f) debt: debt ratio,
(g) $\mathrm{r}$ E/S: expected growth rate of earnings per share,
(h) $\operatorname{var}(\mathrm{E} / \mathrm{S})$ : variance of earnings per share over time.

3. **, *, and \# denote statistical significance at $1 \%, 5 \%, 10 \%$ level, respectively. 
Table 2. Results from the fixed effects and the random effects models

Regression of price-earnings ratio on equity ownership, variance of management shareholding, change in management shareholding, dividend per share, debt ratio, expected growth rate of earnings per share, and variance of earnings per share.

\begin{tabular}{|c|c|c|c|c|}
\hline & \multicolumn{2}{|c|}{ fixed effect model } & \multicolumn{2}{|c|}{ random effect model } \\
\hline & (1) & (2) & (3) & (4) \\
\hline intercept & - & - & $\begin{array}{c}14.86^{* *} \\
(13.01)\end{array}$ & $\begin{array}{l}16.69 * * \\
(16.62)\end{array}$ \\
\hline insider & $\begin{array}{c}-0.09 \\
(-1.61)\end{array}$ & $\begin{array}{l}-0.13^{*} \\
(-2.33)\end{array}$ & $\begin{array}{c}0.00 \\
(0.07)\end{array}$ & $\begin{array}{c}-0.03 \\
(-1.09)\end{array}$ \\
\hline var(insider) & $\begin{array}{c}-0.17 \\
(-2.06 \mathrm{E}-15)\end{array}$ & & $\begin{array}{c}-0.06^{* *} \\
(-3.01)\end{array}$ & \\
\hline change(insider) & & $\begin{array}{l}0.13 * \\
(2.17)\end{array}$ & & $\begin{array}{l}0.18^{*} \\
(2.21)\end{array}$ \\
\hline dividend & $\begin{array}{c}1.40 \\
(1.69)\end{array}$ & $\begin{array}{c}0.18 \\
(0.12)\end{array}$ & $\begin{array}{c}3.23 * * \\
(2.80)\end{array}$ & $\begin{array}{c}0.78 \\
(0.87)\end{array}$ \\
\hline debt & $\begin{array}{c}-0.26 \\
(-0.15)\end{array}$ & $\begin{array}{l}-0.45 \\
(-0.27)\end{array}$ & $\begin{array}{l}-4.07^{*} \\
(-2.07)\end{array}$ & $\begin{array}{c}-8.47 * * \\
(-4.74)\end{array}$ \\
\hline $\mathbf{r}_{-} \mathbf{E} / \mathbf{S}$ & $\begin{array}{c}3.55 * * \\
(4.85)\end{array}$ & $\begin{array}{l}3.56^{* *} \\
(4.84)\end{array}$ & $\begin{array}{l}3.73 * * \\
(4.43)\end{array}$ & $\begin{array}{l}3.31 * * \\
(3.51)\end{array}$ \\
\hline $\operatorname{var}(\mathbf{E} / \mathbf{S})$ & $\begin{array}{c}15.37 \\
(9.77 \mathrm{E}-16)\end{array}$ & $\begin{array}{c}13.04 \\
(8.23 \mathrm{E}-16)\end{array}$ & $\begin{array}{l}-2.08 \# \\
(-1.81)\end{array}$ & $\begin{array}{c}-1.1 \\
(-1.25)\end{array}$ \\
\hline
\end{tabular}

1. Within parentheses are t-values.

2. Variables are defined as follows.
(a) insider: fraction of management share (\%),
(b) insider+block: sum of management share and outside block holder share (\%),
(c) var(insider): variance of "insider" over time,
(d) change(insider): change in "insider" between the previous year and the current year,
(e) dividend: dividend per share,
(f) debt: debt ratio,
(g) r_E/S: expected growth rate of earnings per share,
(h) $\operatorname{var}(\mathrm{E} / \mathrm{S})$ : variance of earnings per share over time.
3. **, *, and \# denote statistical significance at $1 \%, 5 \%, 10 \%$ level, respectively. 
Among other results are that high debt ratio and volatility in earnings per share have negative impact on firm's market value, whereas high dividend payment and high expected growth of earnings have positive effects.

In table 2, we report the estimation results from fixed effects and random effects models. There are trade-offs between the two panel data models. The fixed effects model better controls for unobserved inter-firm differences and better addresses the potential endogeneity problem of the management ownership variable, whereas the random effect model is more parsimonious in terms of the parameters being estimated. Alternatively speaking, the fixed effects model loses too many degrees of freedom, whereas the random effects model does not address the potential endogeneity of the management ownership variable and only partially controls for the unobserved interfirm differences.

The results in table 2 again suggest that management ownership history matters and that once the variance of or change in management ownership is controlled the management shareholding itself does not have any significant effect on the firm value. Most results agree with the corresponding results in Table 1. Statistical significance drops though in Table 2, particularly so in the case of fixed effect models.

Even with limited data, it is suggestive that the history of management shareholding be crucial in determining the firm value. First, market participants ask a discount when they trade equities of a firm of which the management is actively involved in trading. Second, market participants are willing to pay premium to buy equities of a firm of which the management recently increases its shareholding.

\section{Concluding remarks}

This paper revisits the issue of analyzing the relation between the insider ownership share and the firm value. Under information asymmetry between the inside management and the outside investors, history of the management ownership affects a firm's value in the following two ways. First, an active insider trading poses the possibility of outsider exploitation by the inside management, depressing the firm value. Second, insider's buying of shares signals positive news on the firm's value in a credible way, increasing the firm value.

Previous cross-sectional studies do not take into account of the management ownership history, resulting in specification errors and biased estimates. This paper, by using panel data of firms in a single industry, shows that the management ownership history indeed matters in determining the firm value as predicted by the information asymmetry arguments. This paper also shows that once the management ownership history is controlled, the level itself of the management ownership is no longer statistically significant.

At the current stage, we think that the sample size is rather small. Therefore, we 
do not want to over-sell the empirical results obtained in this paper. Rather, we would like to point out that our hypotheses deserve further empirical investigation. A more in depth study will be reported in a near future.

With a bigger data set in the future, we are planning to address the following issues. First, we test endogeneity of the management ownership variable using Hausman and Taylor's (1981) IV/GLS techniques. Second, we allow for a non-linear relationship between the management ownership and the firm value by specifying a flexible linear spline function of the management ownership variable.

Third, we measure the firm value using both market value and profit rate, and see whether the relation between the firm value and the management ownership would be relatively more negative in the case of using the market value as the dependent variable than in the case of using the profit rate as the dependent variable. More specifically, we test the hypothesis that between management ownership and profit rate there be no significant relation or slightly negative relation in the range of high management ownership level, and the hypothesis that there be negative relation between management ownership and firm's market value. 


\section{References}

Bagnani, E., T. Nikolaos, A. Saunders, and N. Travlos (1994), "Managers, owners, and the pricing of risky debt: an empirical analysis," Journal of Finance, June 1994, 453-477.

Berle, A. Jr., and G. Means (1932), The modern corporation and private property, New York: Macmillan.

Demsetz, H. (1983), "The structure of ownership and the theory of the firm," Journal of Law and Economics, 26, 375-390.

Demsetz, H. (1995), The Economics of the Business Firm, New York: Cambridge University Press.

Demsetz, H., and K. Lehn (1985), "The structure of corporate ownership: Causes and consequences," Journal of Political Economy, 93, 1155-1177.

Fama, E. (1980), "Agency problems and the theory of the firm," Journal of Political Economy, 88, 288-307.

Fama, E., and M. Jensen (1983), "Separation of ownership control," Journal of Law and Economics, 26, 301-325.

Hart, O. (1983), "The market mechanism as an incentive scheme," Bell Journal of Economics, 14, 366-382.

Hausman, J., and W. Taylor (1981), "Panel data and unobservable individual effects," Econometrica, 49, 1377-1398.

Jensen, M., and W. Meckling (1976), "Theory of the firm: Management behavior, agency costs and ownership structure," Journal of Financial Economics, 3, 305-360.

Jensen, M., and R. Ruback (1983), "The market for corporate control: The scientific evidence," Journal of Financial Economics, 11, 5-50.

McConnell, J., and H. Servaes (1990), "Additional evidence on equity ownership and corporate value," Journal of Financial Economics, 27, 595-612.

Morck, R., A. Shleifer, and R. Vishny (1988), "Management ownership and market valuation," Journal of Financial Economics, 20, 293-315.

Seyhun, H. (1992), "The effectiveness of the insider-trading sanctions," Journal of Law and Economics, 35, 149-182. 
Stulz, R. (1988), "Managerial control of voting rights, financing policies and the market for corporate control," Journal of Financial Economics, 20, 25-54. 